УДК 373.31

DOI https://doi.org/10.32782/apv/2021.6.16

\title{
Вікторія ХРОМОВА
}

кандидат педагогічних наук, доцент кафедри зарубіжної філології, Таврійський національний університет імені В. І. Вернадського, вул. Джона Маккейна 33, м. Київ, Украӥна, 01042

ORCID: 0000-0001-8573-4158

\section{Сгор БОЙЧЕНКО}

студент II курсу магістратури, Таврійський наџіональний університет імені В. I. Вернадського, вул. Джона Маккейна, 33, м. Київ, Украӥна, 01042

ORCID: 0000-0002-9711-6952

Бібліографічний опис статті: Хромова, В., Бойченко, С. (2021). Обгрунтування ролі освітніх інформаційно-комунікаційних технологій для закладів початкової загальної освіти в умовах пандемії коронавірусної інфекції. Acta Paedagogica Volynienses, 6, 101-107, doi: https://doi.org/10.32782/apv/2021.6.16

\section{ОБГРУНТУВАННЯ РОЛІ ОСВІТНІХ ІНФОРМАЦІЙНО-КОМУНІКАЦІЙНИХ ТЕХНОЛОГІЙ ДЛЯ ЗАКЛАДІВ ПОЧАТКОВОЇ ЗАГАЛЬНОЇ ОСВІТИ В УМОВАХ ПАНДЕМІЇ КОРОНАВІРУСНОЇ ІНФЕКЦЇ̈}

У статті визначена роль освітніх інформаційно-комунікаційних технологій у прочесах організації дистанційних занять для закладів початкової загальної освіти в умовах пандемії коронавірусної інфекції. Доведено, щзо передумовами становлення інформаційного суспільства в Україні стали зміни у швидкості розповсюдження інформації та розширення доступу до інформащійних ресурсів. Інформаційний розвиток суспільства спирається на залучення найсучасніших засобів інформації, інформаційно-комунікаційних технологій. Він відображає досягнутий рівень інформаџійного менеджменту у суспільстві та ступінь ефективності створення, зберігання, опраџювання, подання й використання інформації, щчо забезпечує цілісне бачення світу, його моделювання, передбачення результатів рішень, які приймаються людиною. Сутність інформаційного розвитку суспільства полягає не лише у готовності використовувати останні досягнення інформаційної технології, а й в умінні сприймати нову інформацію.

Обірунтовано, щзо під інформаційно-комунікаційними технологіями пропонується розуміти комплекс об 'єктів, дій і правил, пов'язаних із підготовкою, переробкою та доставкою інформації при персональній, масовій $і$ виробничій комунікації, а також всі технологї і галузі, які інтегрально забезпечують перелічені процеси. Інформаційно-комунікаційні технології є узагальнюючим поняттям, щзо описує різні пристрої, механізми, способи, алгоритми обробки інформації. Найважливішими сучасними пристроями, щчо використовуються в освітньому прочесі, можна вважати комп'ютер, оснащений відповідним програмним забезпеченням, $i$ засоби телекомунікачій разом із розміщеною в них інформацією.

Доведено, щуо симбіоз сформованого інформаційного суспільства в Украӥні та оголошення загальнонаціонального карантину стало запорукою прочесів формування нової форми освіти, заснованої на інформаџійно-комунікаційних технологіях. Доведено, щзо проблема використання інформаційно-комунікаційних технологій полягає у забезпеченні освітнього процесу відповідними технологіями і залежить від людського чинника, який визначається саме у відсутності необхідних навичок у викладачів початкової школи щзодо їх застосування.

Ключові слова: інформаційно-комунікаційні технологї̈, початкова загальна освіта, пандемія коронавірусної інфекції, організація дистанційних занять, освітні технологї.

\section{Victoria KHROMOVA}

Candidate of Sciences in Pedagogy, Associate Professor at the Department of Foreign Philology, V. I. Vernadsky Taurida National University, John McCain str., 33, Kyiv, Ukraine, 01042

ORCID: 0000-0001-8573-4158

\section{Yehor BOICHENKO}

Master Student, V. I. Vernadsky Taurida National University, John McCain str., 33, Kyiv, Ukraine, 01042 ORCID: 0000-0002-9711-6952 
To cite this article: Khromova, V., Boychenko, E. (2021). Obgruntuvannia roli osvitnikh informatsiino-komunikatsiinykh tekhnolohii dlia zakladiv pochatkovoi zahalnoi osvity $\mathrm{v}$ umovakh pandemii koronavirusnoi infektsii [Justification of the role of educational information and communication technologies for Primary general education institutions in the context of the coronavirus pandemic]. Acta Paedagogica Volynienses, 6, 101-107, doi: https://doi.org/10.32782/apv/2021.6.16

\section{JUSTIFICATION OF THE ROLE OF EDUCATIONAL INFORMATION AND COMMUNICATION TECHNOLOGIES FOR PRIMARY GENERAL EDUCATION INSTITUTIONS IN THE CONTEXT OF THE CORONAVIRUS PANDEMIC}

The article defines the role of educational information and communication technologies in the organization of distance learning for Primary general education institutions in the context of the coronavirus pandemic. It is proved that the prerequisites for the formation of the information society in Ukraine were changes in the speed of information dissemination and expansion of access to information resources. The information development of society is based on the involvement of the most modern Information Media, Information, and communication technologies. It reflects the achieved level of Information Management in society and the degree of effectiveness of creating, storing, processing, presenting, and using information that provides a holistic vision of the world, it's modeling, and predicting the results of decisions made by a person. The essence of Information development of society is the readiness not only to use the latest achievements of information technology but also in the ability to perceive new information.

It is proved that information and communication technologies are proposed to be understood as a set of objects, actions, and rules related to the preparation, processing, and delivery of information in personal, mass, and industrial communication, as well as all technologies and industries that integrally provide the listed processes. Information and communication technologies are generalizing concept that describes various devices, mechanisms, methods, and algorithms for information processing. The most important modern devices used in the educational process can be considered a computer equipped with appropriate software, and telecommunications facilities along with the information placed in them.

It was established that the symbiosis of the existing information society in Ukraine and the announcement of a nationwide quarantine has become the key to the formation of a new form of Education based on information and communication technologies. It is proved that the problem of using information and Communication Technologies is not only to provide the educational process with appropriate technologies but also, among other things, from the human factor, which is determined precisely in the lack of necessary skills for primary school teachers in their application.

Key words: information and communication technologies, Primary general education, coronavirus pandemic, Organization of distance learning, educational technologies.

Актуальність проблеми. Сучасний розвиток людства відбувається в умовах величезного виклику, з яким стикнулось суспільство - пандемії коронавірусної інфекції SARS-CoV-2. Зусилля усіх держав світу спрямовані на запобігання пандемії, яке виявилося у самоізоляції соціуму (соціальному дистанціюванні), що стало одним із дієвих заходів стримування розповсюдження SARS-CoV-2. Можна спрогнозувати, що соціальні наслідки цих процесів будуть вивчатися досить тривалий час. Це пов'язано 3 тим, що пандемія коронавірусної інфекції «втрутилася» майже в усі сфери та процеси життєдіяльності соціуму. Розмірковуючи над процесами відтворення життєдіяльності в контексті нової реальності - самодистанціювання, можна стверджувати, що наслідками пандемії, окрім явного негативного впливу (погіршення суспільного здоров'я, «надлишкова» смертність від хвороб, спричинених коронавірусною інфекцією, негативні тенденції в економіці тощо), можна назвати активізацію процесів діджиталізації суспільства. Саме використання сучасних інформаційних та комунікаційних технології дозволяє залишатися на зв'язку багатьом людям і продовжувати своє навчання.

Суттєві зміни, що спричинені коронавірусною інфекцією, вплинули й на організацію початкової загальної освіти. I насамперед це стосується використання в навчальному процесі інформаційно-комунікаційних технологій, що дало можливість перевести освітній процес у дистанційний формат. Ситуація несподіванки та стрімкого переходу від традиційного до онлайн-формату навчання викликали чимало проблем в організації навчального процесу та якості отриманих знань учнів початкової школи.

Аналіз останніх досліджень i публікацій. Дослідженню проблем використання ролі освітніх інформаційно-комунікаційних технологій для закладів початкової загальної освіти присвячені праці багатьох як закордонних, так і вітчизняних науковців. Питання визна- 
чення сутності та ролі інформаційного суспільства розкриті в працях провідних науковців, таких як: О. Матвієнко, Н. Мороз, В. Плескач, F. Machlup, Y. Masuda, А. Коломієць та інші; застосування сучасних інформаційно-комунікаційних технологій для освіти висвітлюється у роботах таких учених, як Л. Білоусова, А. Гуржій, Ю. Жидецький, М. Кадемія, А. Пилипчук, I. Роберт, К. Словак, Т. Якимович та інші; дослідження проблем використання освітніх інформаційно-комунікаційних технологій для закладів початкової загальної освіти, комп'ютерно-орієнтованих систем навчання здійснено у працях таких чених, як: I Андрощук, Л. Дзюба-Шпурик, О. Кравчук, О. Олексюк, В. Олійник, І Остапйовська, О. Суховірський та інші. Обгрунтування ролі освітніх інформаційно-комунікаційних технологій для закладів початкової загальної освіти потребують додаткового теоретико-методичного обгрунтування, викликаного сучасними умовами відтворення суспільного життя в умовах пандемії коронавірусної інфекції.

Метою дослідження $\epsilon$ визначення ролі освітніх інформаційно-комунікаційних технологій у процесах організації дистанційних занять для закладів початкової загальної освіти в умовах пандемії коронавірусної інфекції.

Виклад основного матеріалу. Виникнення глобальної пандемії коронавірусної інфекції SARS-CoV-2 прискорило впровадження нових інформаційно-комунікаційних технологій в освітній процес практично на всіх іiі рівнях. Використання інформаційнокомунікаційних технологій стало можливим за умов сформованого в Україні інформаційного суспільства. Передумовами становлення інформаційного суспільства в Україні стали зміни у швидкості розповсюдження та розширення доступу до інформаційних ресурсів (Бойченко, Костенко, 2018).

Термін «інформаційне суспільство» було введено у науковий обіг на початку 60 -х років фактично одночасно у США та Японії Ф. Махлупом і Т. Умесао (Махлуп, 2000). У кінці 20-го століття термін «інформаційне суспільство» отримав визнання після виходу в світ книги I. Масуди (Масуда, 1981) і праць американських та європейських дослідників, які стали акцентувати увагу на ролі і значенні не стільки інформації, скільки знань.
Починаючи з 1992 р. термін «інформаційне суспільство» стали вживати у багатьох західних країнах відповідно до визначення Сврокомісії, згідно з яким інформаційним називається суспільство, в якому діяльність людей здійснюється на основі послуг, наданих за допомогою інформаційних технологій і технологій зв'язку (Шишкина, 2019).

Наприкінці XX століття терміни «інформаційне суспільство» та «інформатизація» міцно зайняли своє місце не тільки в лексиконі фахівців у сфері інформації, але і в лексиці політичних діячів, економістів, викладачів i вчених. Здебільшого це поняття асоціювалося з розвитком інформаційних технологій і засобів телекомунікації. 27 березня 2006 року Генеральна Асамблея ООН прийняла резолюцію під номером A/RES/60/252, яка проголосила 17 травня Міжнародним днем інформаційного суспільства.

Передумовами становлення інформаційного суспільства в Україні стали зміни у швидкості розповсюдження інформації та розширення доступу до інформаційних ресурсів. Доцільно позначити низку базових ознак інформаційного суспільства (Шишкина, 2019):

- становлення інформаційного суспільства пов'язано із домінуванням інформаційного сектору економіки. Визначальним фактором розвитку суспільства стають знання;

- рівень знань стає визначальним фактором соціальної диференціації і соціальної мобільності;

- інфраструктурою інформаційного суспільства стає нова «інтелектуальна» техніка.

Інформаційний розвиток суспільства спирається на залучення найсучасніших засобів інформації, інформаційно-комунікаційних технологій. Він відображає досягнутий рівень інформаційного менеджменту у суспільстві та ступінь ефективності створення, зберігання, опрацювання, подання й використання інформації, що забезпечує цілісне бачення світу, його моделювання, передбачення результатів рішень, які приймаються людиною. Сутність інформаційного розвитку суспільства полягає не лише у готовності використовувати останні досягнення інформаційної техніки, а й в умінні сприймати нову інформацію.

Таким чином, інформаційні технології і засоби інформації стають умовами розвитку 
людини, визначають стиль та спосіб iі життя (Бойченко, Костенко, Дроботенко 2019).

Розглядаючи ролі освітніх інформаційно-комунікаційних технологій в умовах формування інформаційного суспільства, виникає необхідність уточнення таких категорій, як «інформація» та «інформаційнокомунікаційні технології».

У перекладі з латинської мови слово «інформація» означає «пояснення», «роз'яснення», «повідомлення». Інформація у загальному вигляді означає відомості про навколишній світ, процеси, які в ньому відбуваються, події, ситуації, явища, які отримують і якими обмінюються люди безпосередньо чи за допомогою певних пристроїв. Із середини XX століття інформація стає загальнонауковим поняттям.

Існування інформаційного суспільства нерозривно пов'язане з усвідомленням фундаментальної ролі інформації, наявністю таких феноменів, як інформаційні ресурси та технології, інформатизація. Інформаційна сфера, рівень розвитку якої визначається кількістю та якістю накопиченої інформації, іiі доступністю, висуває на перший план інформацію як одне з головних джерел іï розвитку (Bakhov, Martynovych, 2020).

Зазначимо, що під інформаційно-комунікаційними технологіями пропонується розуміти комплекс об'єктів, дій і правил, пов'язаних із підготовкою, переробкою та доставкою інформації при персональній, масовій і виробничій комунікації, а також всі технології і галузі, які інтегрально забезпечують перераховані процеси.

Інформаційно-комунікаційні технології доцільно розглядати як узагальнююче поняття, що описує різні пристрої, механізми, способи, алгоритми обробки інформації. Найважливішими сучасними пристроями, що використовуються в освітньому процесі, можна вважати комп'ютер, оснащений відповідним програмним забезпеченням, і засоби телекомунікацій разом з розміщеною в них інформацією (Биков, 2013; Биков, 2010).

Інформаційно-комунікаційні технології у сфері освіти представлені презентаційними програмами зі спеціалізованим дизайном PowerPoint, що мають простий стандарт для представлення спеціалізованих знань. Крім того, можуть використовуватися такі про- грами, як Zoom, Skype, Moodle, Google-клас тощо, що пропонують різні можливості для інтерактивної голосової та візуальної комунікації, зберігання відповідей, онлайн-оцінки отриманих знань. Вікі-сайти використовуються багатьма освітніми організаціями (Гуревич, Кадемія, Шевченко, 2012), полегшуючи дистанційне навчання та створюючи спільне робоче середовище між студентами, школярами та викладачами. Спостерігається стрімке зростання цифрової грамотності, що прискорюється необхідністю спілкування в умовах соціальної дистанції.

За період розвитку інформаційного суспільства i поширення Інтернет-технологій IT-спеціалістами різних країн було створено значну кількість ресурсів і каналів передачі і поширення інформації, які під час епідемії могли використовувати люди для організації й забезпечення не тільки освітніх процесів, а й іншої сфери своєї життєдіяльності: навчальної, професійної, розважальної тощо. Аналіз, узагальнення та систематизація Інтернет-ресурсів i сервісів дозволяє визначити шляхи застосування інформаційно-комунікаційних технологій та їх значення під час таких широкомасштабних пандемій, як епідемія хвороби COVID-19, що спричинена вірусом SARS-CoV-2.

Однією 3 проблем, що виникли в Україні, стала організація навчального процесу в усіх навчальних закладах країни в умовах локдауну, яка пов'язана із забезпеченням дистанційного освітнього процесу необхідним обладнанням та мережею Інтернет.

Таким чином, можна стверджувати, що симбіоз сформованого інформаційного суспільства в Україні та оголошення загальнонаціонального карантину стало запорукою процесів формування нової форми освіти, заснованої на інформаційно-комунікаційних технологіях.

Слід зазначити, що розвиток інформаційно-комунікаційних технологій відбувається настільки стрімко, що педагогічна наука не встигає за технічним прогресом. Аналіз засобів інформаційно-комунікаційних технологій показав збільшення ролі електронних засобів в навчальному процесі. Сучасні інформаційно-комунікаційні технології, що використовуються у освітньому процесі, істотно відрізняються від попередніх аналогів, вони 
видозмінюються і призводять до перегляду існуючих методів навчання. Важливим напрямом стає розвиток інтерактивних засобів навчання, під якими розуміють програмні та технічні засоби і пристрої, що функціонують на базі мікропроцесорної та обчислювальної техніки, що забезпечує навчання в діалоговій взаємодії користувача 3 комп'ютером (Гуревич, Кадемія, Шевченко, 2012).

У зв'язку з вищезазначеним можна відзначити, що використання інформаційно-комунікаційних технологій в початковій школі має суттєві відмінності від їх використання на вищих (наступних) рівнях освіти. Однією 3 головних проблем можна вважати непідготовленість більшої частини учнів, а в деяких випадках і вчителів, до самостійного застосування сучасних інформаційно-комунікаційних технологій та відсутність часу для їх освоєння. Так, учитель початкової школи, окрім професійних знань, повинен володіти навичками використання інноваційного інтерактивного обладнання для організації освітнього процесу. Таким чином, можна стверджувати, що проблема використання інформаційно-комунікаційних технологій полягає не тільки у забезпеченні освітнього процесу відповідними технологіями, а й залежить від людського чинника, який визначається саме у відсутності необхідних навичок у викладачів початкової школи у їх застосуванні.

Для подолання цієї проблеми потрібне вирішення цілої низки завдань. Зокрема, освоєння вчителями технологій дистанційного навчання, оволодіння ними методик використання інноваційних технологій дистанційної освіти та форм їх реалізації, створення онлайн-форм для оцінювання знань, отримання знань та практичних навичок щодо створення віртуальних навчальних класів, створення аудіовізуального супроводу навчальних занять тощо. Слід звернути увагу на те, що у сучасному суспільстві «інформаційна грамотність» та «інформаційна культура» стають запорукою успішної професійної діяльності вчителя. Чим ефективніше організована робота 3 підвищення кваліфікації вчителів, тим швидше втілюється їх можливість використання інноваційних інформаційно-комунікаційних технологій у своїй педагогічній діяльності, тим результативніше вони можуть використовувати новітні методи навчання.
Таким чином, використання інформаційнокомунікаційних технологій $\epsilon$ необхідною умовою сучасної організації навчального процесу у початковій школі, яка покликана виконувати особливу роль, що дозволяє організувати та здійснювати освітню діяльність. В сучасних реаліях вона повинна виконувати не тільки організаційну функцію, але і забезпечити умови для підвищення мотивації навчання учнів початкових класів, раціональної організації навчального процесу, розумінню і засвоєнню навчального матеріалу тощо.

До переваг нової форми освіти можна віднести швидкий доступ до різноманітних наукових ресурсів та міжнародних наукометричних баз даних; відкритий, інтерактивний і міждисциплінарний спосіб взаємодії «вчитель-учень» та «учень-учитель»; доступ до різних відеоматеріалів, навчальних посібників, які допомагають у вивченні інформації тощо. До недоліків можна віднести недостатній рівень цифрових навичок, що призвело до проблем організації навчального процесу в онлайн-середовищі; проблеми 3 високошвидкісним інтернет зв'язком у сільській місцевості, а також його перевантаження; відсутність технологічних можливостей у багатьох українських сім'ях, що ускладнює процес навчання в онлайн-середовищі тощо.

3 метою поліпшення організації дистанційного освітнього процесу повинна бути створена стратегія цифровізації української освіти, яка матиме такі пріоритети:

- створення доступності цифрової інфраструктури для всіх зацікавлених сторін - учасників дистанційної освіти;

- надання доступу до вільного використання освітніх ресурсів, до цифрової грамотності;

- створення науково-освітньої спільноти, метою діяльності якої повинно стати підвищення якості знань учнів;

- створення високопродуктивного цифрового освітнього середовища, що забезпечується етикою та захистом персональних даних;

- використання інновацій в освітній діяльності;

- забезпечення стабільності та безперервності освітнього процесу;

- інституціоналізація нових способів навчання тощо.

Серед науковців немає єдиної думки щодо доцільності використання інформаційно- 
комунікаційних технологій у навчальних цілях та їх впливу на якість освітнього процесу. Це пов' язано з тим, що організація дистанційного освітнього процесу не забезпечує концентрації уваги та активності учнів, не дозволяє у повній мірі контролювати їх роботу. Виникають проблеми у контролі виконання індивідуальних та домашніх завдань, засвоєнні учнем навчального матеріалу тощо. Інші дискусійні питання у використанні інформаційно-комунікаційних технологій полягають у правовій площині, а саме у вразливості персональних даних учнів та викладачів. Виникають питання захисту персональних даних, неможливості їх оприлюднення та розповсюдження.

3 погляду забезпечення принципу наочності, використання інформаційно-комунікаційних технологій створюються умови для реалізації таких можливостей:

- раціональної організації пізнавальної діяльності учнів початкової школи;

- активізації роботи учнів в процесі проведення уроків;

- емоційного сприйняття навчального матеріалу;

- забезпечення відкритої системи навчання та створення індивідуальної траєкторії навчання учнів тощо.

Отже, інформаційно-комунікаційні технології надають значні можливості для професійної діяльності викладача, а також сприяють різнобічному розвитку учнів. Таким чином, використання інформаційно-комунікаційних технологій створює умови для організації індивідуального підходу та диференціації навчального процесу, забезпечення ефективної організації освітньої діяльності учнів початкової школи, підвищення якості засвоєння навчального матеріалу, що забезпечує успішність їх навчання. Використання інформаційно-комунікаційних технологій в освітньому процесі стає необхідною умовою їх продовження в забезпеченні результативності та ефективності освітнього процесу.

Висновки. За результатами дослідження можна зробити висновки, наведені нижче.
Виникнення глобальної пандемії коронавірусної інфекції SARS-CoV-2 прискорило впровадження нових інформаційно-комунікаційних технологій в освітній процес практично на всіх його рівнях. Використання інформаційнокомунікаційних технологій стало можливим за умов сформованого в Україні інформаційного суспільства.

Інформаційний розвиток суспільства спирається на залучення найсучасніших засобів інформації, інформаційно-комунікаційних технологій. Він відображає досягнутий рівень інформаційного менеджменту у суспільстві та ступінь ефективності створення, зберігання, опрацювання, подання й використання інформації, що забезпечує цілісне бачення світу, його моделювання, передбачення результатів рішень, які приймаються людиною.

Симбіоз сформованого інформаційного суспільства в Україні та оголошення загальнонаціонального карантину стало запорукою процесів формування нової форми освіти, заснованої на інформаційно-комунікаційних технологіях.

Використання інформаційно-комунікаційних технологій в умовах пандемії коронавірусної інфекції SARS-CoV-2 показує, наскільки вони виявилися важливими як в освіті, так і в інших сферах життєдіяльності суспільства, а також доводить необхідність їх розвитку та впровадження в умовах інформаційного суспільства.

Використання інформаційно-комунікаційних технологій у початковій школі має суттєві відмінності від їх використання на вищих (наступних) рівнях освіти. Можна стверджувати, що проблема використання інформаційно-комунікаційних технологій полягає у забезпеченні освітнього процесу відповідними технологіями, окрім цього, залежить від людського чинника, який визначається саме у відсутності необхідних навичок у викладачів початкової школи.

Використання інноваційних інформаційно-комунікаційних технологій у поєднанні 3 традиційними методами навчання сприяє підвищенню якості навчання учнів та створює умови для забезпечення принципу наочності у навчанні.

\section{ЛІТЕРАТУРА:}

1. Бойченко Е.Б., Костенко А.М. Концепція формування інформаційного менеджменту в Україні. Ефективна економіка. 2018. № 10. URL: http://www.economy.nayka.com.ua/?op=1\&z=7159 (дата звернення: 19.09.2021). 
2. Бойченко Е.Б., Костенко А.М., Дроботенко Я.М. Особливості відтворення регіонального соціуму в умовах інформаційного суспільства. Збірник наукових праџь Донецького державного університету управління. Серія "Економіка" Т. ХХ, вип. 311. Маріуполь, ДонДУУ, 2019. С. 14-26.

3. Биков В.Ю. Мобільний простір і мобільно орієнтоване середовище інтернет-користувача: особливості модельного подання та освітнього застосування. Інформаиійні технології в освіті. 2013. Вип. 17. С. 9-37. URL: http://nbuv.gov.ua/UJRN/itvo_2013_17_3 (дата звернення: 1.10.2021).

4. Биков В.Ю. Сучасні завдання інформатизації освіти. Інформаційні технології і засоби навчання. 2010. № 1(15). URL: http://www.ime.edu-ua.net/em.html (дата звернення: 1.10.2021).

5. Гуревич Р.С., Кадемія М.Ю., Шевченко Л.С. Інформаційні технології навчання: інноваційний підхід : навч. посіб. Вінниця : ТОВ фірма «Планер» 2012. 348 с.

6. Электронная нервная система для государственных служб. URL: http://www.microsoft.com/rus/government/ whitepapers (дата звернення: 19.09.2021).

7. Современная концепция информационного общества: тексты лекций для магистрантов специальности 1-23 8005 «Журналистика» / сост. Н. И. Шишкина. Минск: БГТУ. 2019. 52 с.

8. Machlup F. Production and Distribution of Knowledgein the UnitedStates. Princenton, 2000. $457 \mathrm{p}$.

9. Masuda Y. The Information Societyas Post-Industrial Society. World Future Society, 1981. 171 p.

10. Ivan S. Bakhov, Nataly O. Martynovych Building Research Work Skillsin Studentsas a Componentof Their Professional Training. Journal of Advanced Researchin Dynamical and Control Systems - JARDCS. 2020. Volume12, 04 - SpecialIssue. P. 840-848. URL: https://www.jardcs.org/abstract.php?id=3465 (дата звернення: 11.10.2021).

\section{REFERENCES:}

1. Bojchenko, E.B., \& Kostenko, A.M. (2018) Koncepcija formuvannja informacijnogho menedzhmentu v Ukrajini [The concept of information management formation in Ukraine] Efektyvna ekonomika-Efficient economy, 10. Retrieved from http://www.economy.nayka.com.ua/?op=1\&z=7159 [in Ukrainian].

2. Bojchenko, E.B., Kostenko, A.M., \& Drobotenko, Ja. M. Osoblyvosti vidtvorennja reghionaljnogho sociumu v umovakh informacijnogho suspiljstva [Features of the creation of the regional society in the minds of the information support]. Zbirnyk naukovykh pracj Donecjkogho derzhavnogho universytetu upravlinnja. Serija "Ekonomika" - Collection of scientific works of Donetsk State University of Management. Economics Series, XX, 311, 14-26 [in Ukrainian].

3. Bykov, V.Ju. (2013). Mobiljnyj prostir i mobiljno orijentovane seredovyshhe internet-korystuvacha: osoblyvosti modeljnogho podannja ta osvitnjogho zastosuvannja [Mobile space and mobile-oriented Internet user environment: features of model presentation and educational application]. Informacijni tekhnologhiji v osviti - Information technology in education, 17, 9-37. Retrieved from http://nbuv.gov.ua/UJRN/itvo_2013_17_3 [in Ukrainian].

4. Bykov, V.Ju. (2010). Suchasni zavdannja informatyzaciji osvity [Modern tasks of informatization of education]. Informacijni tekhnologhiji i zasoby navchannja - Information technologies and teaching aids, 1 (15). Retrieved from http://www.ime.edu-ua.net/em.html [in Ukrainian].

5. Ghurevych, R.S., Kademija, M.Ju., \& Shevchenko, L. S. (2012) Informacijni tekhnologhiji navchannja: innovacijnyj pidkhid : navch. posib. [Learning information technologies: an innovative approach: a textbook] Vinnycja : TOV firma «Planer» [in Ukrainian].

6. Jelektronnaja nervnaja sistema dlja gosudarstvennyh sluzhb [Electronic nervous system for government services] (n.d.). Retrieved from http://www.microsoft.com/rus/government/whitepapers [in Ukrainian].

7. Shishkina N.I. (2019) Sovremennaja koncepcija informacionnogo obshhestva: teksty lekcij dlja magistrantov special'nosti 1-23 8005 "Zhurnalistika» [The modern concept of the information society: texts of lectures for undergraduates specialty 1-23 8005 "Journalism"]. Minsk: BGTU [in Belarus].

8. Machlup F. (2000). Production and Distribution of Knowledgein the United States [Production and Distribution of Knowledgein the United States]. Princeton: University Press [in the United States of America].

9. Masuda Y. (1981). The information society as post-industrial society [The information society as post-industrial society]. Tokyo: Institute for the Information Society [in Japan].

10. Ivan S. Bakhov, Nataly O. Martynovych Building Research Work Skillsin Studentsas a Componentof Their Professional Training. Journal of Advanced Researchin Dynamical and Control Systems - JARDCS. 2020. Volume12, 04 - SpecialIssue. P. 840-848. URL: https://www.jardcs.org/abstract.php?id=3465 (дата звернення: 11.10.2021) [in the United States of America]. 